\title{
THE TENTACLES OF MAJORITARIANISM: HOW FAR CAN THEY REACH INTO RETRENCHMENT?*
}

\author{
Rochelle Le Roux \\ BJuris LLB LLM PG Dip (Employment Law and \\ Social Security) LLM PhD \\ Professor, Faculty of Law \\ University of Cape Town
}

SUMMARY

Majoritarianism enables a trade union with a majority in the workplace to prevail over minority unions and their members as well as non-unionised employees and to limit some of the minority's rights, including the right to strike. This article revisits the basic tenets of majoritarianism and calls for a more nuanced distinction between legislative provisions giving special privileges to majority unions and those provisions that enable majority unions to prevail over minority unions. Ultimately, the focus of the article is on the interface between majoritarianism and retrenchment. While it argues that there is legitimate scope for a collective agreement concluded after retrenchment consultations to be extended to the members of minority unions, the article expresses reservations whether a collective agreement regarding the identity of consulting parties in the case of retrenchment can similarly be extended. Nonetheless, the article concedes that the model of majoritarianism informing the Labour Relations Act (LRA) possibly lacks the subtlety to accommodate this distinction.

\section{INTRODUCTION}

Majoritarianism is not defined in the Labour Relations Act, ${ }^{1}$ but the Constitutional Court has explained that it merely means that the will of the majority will prevail over that of the minority. ${ }^{2}$ Nonetheless, majoritarianism is a premise of the LRA, and a number of the LRA's provisions either give effect to the principle or, at least, aid its expression.

This is a revised version of a paper presented at the Labour Law Alumni Conference on Collective Bargaining, hosted by the Faculty of Law, Nelson Mandela University from 19-20 July 2019 in Port Elizabeth. The author is grateful to the delegates for their invaluable questions and comments which helped to shape the revision. The author's sincere thanks also goes to Dr Emma Fergus for her very helpful views on minority unions. Any errors are entirely the author's.

66 of 1995. Henceforth, unless indicated otherwise, all references to legislative provisions are to the LRA.

2 Transport \& Allied Workers Union of SA v Putco Ltd 2016 (4) SA 39 (CC) (Putco) par 61. 
Although majoritarianism is a premise, its full impact was not immediately apparent when the LRA was passed. Nevertheless, as an understanding of the LRA and its jurisprudence is maturing, the long reach of the tentacles of majoritarianism, also in the case of operational requirement dismissals (retrenchment), is beginning to show, raising new questions about its validity.

Ultimately, this article is about the manifestations of majoritarianism in the context of retrenchment. However, in order to do justice to this focus, the general import of majoritarianism in the context of the LRA will first be explored.

This article is structured as follows: Part 2 reviews the general import of majoritarianism under the LRA, and this is followed by an analysis of the two key building blocks of majoritarianism, namely, a "collective agreement" and the "workplace". Part 2 also explores the possibility of challenging the legality of an extension of a collective agreement to non-parties. Part 3 explores the manifestation of majoritarianism in retrenchment situations. This requires an evaluation of the nature of retrenchment consultations and the role of collective agreements in identifying consulting parties and in settling retrenchment consultations. This is followed by concluding remarks in Part 4.

\section{THE LRA AND MAJORITARIANISM}

\section{Introduction}

Majoritarianism enables a trade union (union) ${ }^{3}$ (or, in certain circumstances, a coalition of unions) ${ }^{4}$ with a majority in the workplace to prevail over a minority union and non-union employees and to limit some of the minority's rights, including the right to strike. Despite these potentially invasive implications of majoritarianism, the Constitutional Court in Association of Mineworkers \& Construction Union v Chamber of Mines of $S A^{5}$ (Chamber of Mines) confirmed that majoritarianism is a founding principle of the LRA and that it is not constitutionally objectionable for the following broad reasons:

- The legislature's main vehicle for expressing majoritarianism, namely, section 23(1)(d) (discussed below), ${ }^{6}$ which allows for extensions of collective agreements to non-parties, is not an instrument of oppression as minority unions still have scope to organise; ${ }^{7}$

- Majoritarianism is functional to collective bargaining, and the LRA model exceeds the threshold of representativity that is envisaged by some international instruments for this purpose ${ }^{8}$ and

\footnotetext{
3 All references to unions and employer organisations assume that they are registered in terms of the LRA.

See s 11 read with ss 14 and 16 .

(2017) 38 ILJ 831 (CC).

See 23 below.

Par 55.

Par 56.
} 
- The limitation on the right to strike through extensions of collective agreements is circumscribed in various ways - in particular, the extension can only relate to issues covered by the extended collective agreement. $^{9}$

This reinforces the insights of the Constitutional Court in Putco. This matter concerned the ability of an employer to lock out employees with whom it is not in dispute, but, in the course of the judgment, the Constitutional Court also considered the extension to non-parties, in terms of section 32, of collective agreements concluded in a bargaining council. Such extension can be made only by the Minister of Labour after a number of parties have voted for the extension. These parties include, amongst others, one or more unions whose members constitute the majority of the union's party to the bargaining council, and one or more employer organisations whose members employ the majority of the employees. ${ }^{10}$ While the Constitutional Court concluded that majoritarianism did not apply to the facts of the matter before it, ${ }^{11}$ the court emphasised that majoritarianism can find "application [only] after a collective agreement has been concluded" (emphasis added) 12 and that "it finds no application to strikes and lock-outs under ss 213 and 64(1)". ${ }^{13}$

This is key to understanding the LRA's model of majoritarianism: It finds expression only once collective agreements are concluded and the legislative requirements for extension have been met. In other words, while majoritarianism advances orderly collective bargaining, it is not a given; the stars, so to speak, must first align before it applies. Care should therefore be taken to distinguish majoritarianism, as a means by which the majority prevails over a minority, from situations where the LRA confers on some unions certain a priori enforceable rights, primarily in the context of union organisation, albeit clearly in support of majoritarianism (and thus also in the interest of orderly collective bargaining). ${ }^{14}$ These organisational rights, however, cannot be used as a means of denying minority unions the right to organise, or of denying individuals the freedom of association, as this would impair constitutional rights and be oppressive. This is a condition precedent for a fair and constitutionally acceptable majoritarian system. In National Union of Metalworkers of SA $\vee$ Bader Bop (Pty) Ltd (Bader Bop), ${ }^{15}$ the Constitutional Court, referring to the views of expert committees of the International Labour Organization (ILO), remarked that majoritarianism could be compatible with freedom of association, provided that "minority unions are allowed to exist, to organise members, to represent members in relation to individual grievances and to seek to challenge majority unions from time to time" (emphasis added). ${ }^{16}$ Echoing these sentiments, the Constitutional Court in Chamber of Mines concluded that the LRA provides sufficient scope

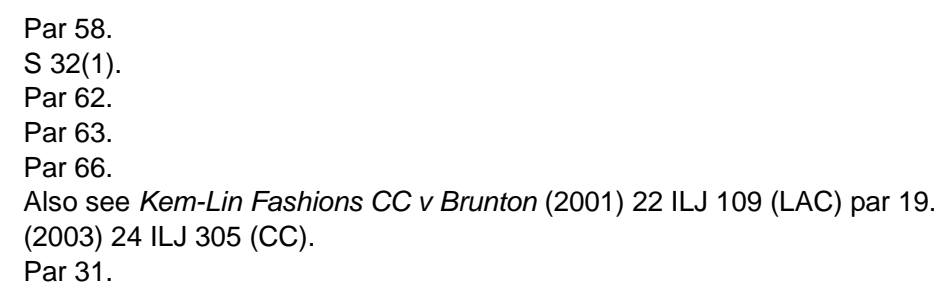


for minority unions to organise "and to canvass support to challenge the hegemony of established unions".

Nonetheless, despite this endorsement by the Constitutional Court, it might be asked whether majoritarianism can dislodge fundamental rights that do not advance collective bargaining. Asked differently: If majoritarianism aims to promote orderly collective bargaining, it is certainly compatible with a limitation of those rights that promote collective bargaining, such as the right to strike, but is it compatible with the limitation of fundamental rights that do not specifically advance collective bargaining? Would this not allow majoritarianism to become the instrument of oppression that the Constitutional Court has cautioned against? These questions will be reverted to in Part 3.

\section{Majority unions and the LRA}

Apart from sections 189 and $189 \mathrm{~A}$, which will be the focus of Part 3, the following are the typical provisions of the LRA where the majority status of a union either affords it some special privileges or enables it to prevail over the minority:

(i) Agency shop agreements (section 25) allow for the deduction of majority union fees from all employees, regardless of whether they are members of that union, and closed shop agreements (section 26) oblige all employees to join the majority union. The constitutionality of these provisions remains untested, but they can be regarded as expressions of majoritarianism as defined in Putco.

(ii) Section 14, now slightly tempered by section $21(8 \mathrm{~A})($ a), allows a majority union to have elected union representatives in the workplace, and section 16 , now tempered by section $21(8 \mathrm{~A})(b)$, entitles a majority union in a workplace to claim the disclosure of information. These provisions give special privileges to majority unions, but are not an expression of majoritarianism as explained in Putco.

(iii) Section 18 allows a majority union and an employer, or the parties to a bargaining council, through a collective agreement, to set the threshold of representativeness for other unions to claim the organisational rights referred to in sections 12,13 and 15 . The apparent bluntness and farreaching implications of this provision have been softened by the insertion of section $21(8 \mathrm{C})$, as well as the interpretation of section 18 by the Constitutional Court majority in Police \& Prisons Civil Rights Union $v$ SA Correctional Services Workers Union (POPCRU), ${ }^{18}$ to the extent that some would argue ${ }^{19}$ that what is left of majoritarianism in section 18 has bark, but no bite:

"When properly construed chapter III of the LRA reveals that a minority union may access organisational rights in ss 12,13 and 15 in a number of ways. First, it may acquire those rights if it meets the threshold set in the collective

7 Par 52-55.

18 (2018) 39 ILJ 2646 (CC).

19 Also see Fergus "The Disorganisation of Organisational Rights - Recent Case Law and Outstanding Questions" 201940 ILJ 685. 
agreement between the majority union and the employer. In that event, a minority union does not have to bargain before exercising the rights in question. Second, such union may bargain and conclude a collective agreement with an employer, in terms of which it would be permitted to exercise the relevant rights. Third, a minority union may refer the question whether it should exercise those rights to arbitration in terms of $\mathrm{s} 21(8 \mathrm{C})$ of the LRA. If the union meets the conditions stipulated in that section, the arbitrator may grant it organisational rights in the relevant provisions.

It is suggested that section 18 merely affords special privileges to unions with a certain level of representation ${ }^{21}$ and is not majoritarianism, as explained in Putco.

(iv) The seldom-used section 78 provides majority trade unions with the power to initiate workplace forums.

(v) Reference has already been made to sections 23 and 32, which provide for the extension of collective of agreements at the instance of a majority. These two provisions, it is suggested, represent the essence of majoritarianism under the LRA. The rest of this article will focus on section $23(1)(d)$.

\section{Section 23(1)(d)}

Section 23(1)(d) provides as follows:

"A collective agreement binds ... employees who are not members of the registered trade union or trade unions party to the agreement if-

i. the employees are identified in the agreement;

ii. the agreement expressly binds the employees; and

iii. that trade union or those trade unions have as their members the majority of employees employed by the employer in the workplace."

At first sight, this provision might appear relatively harmless, but read with section 65, which prohibits striking by anyone bound by a collective agreement regulating the issue in dispute, its full might become clear: It limits the right to strike of employees who are not members of the union party to the collective agreement.

Key to the application of this section is (1) the existence of a collective agreement, (2) a transacting union or unions that has or have the majority ${ }^{22}$ in (3) the workplace. Furthermore, the collective agreement must (4) identify the non-party employees who would be bound by the agreement, and the collective agreement must (5) expressly bind these employees. Given the far-reaching implications of an extension, the latter requirement is understandable; when the rights of non-party employees are to be limited, there must be no doubt about it. In this regard, it has been held that "[n]on-

\footnotetext{
Par 101.

Bader Bop par 40

In Association of Mineworkers \& Construction Union v Sibanye Gold Ltd t/a Sibanye Stillwater (2) (2019) 40 ILJ 1607 (LC) it was held that a collective agreement can be extended in terms of $s 23(1)(d)$ once the union party achieves a majority even if it did not have a majority when the agreement was concluded. The court further held that, provided that the union party had majority status at the time of the extension, the extension can have both prospective and retrospective application.
} 
parties cannot be bound as contemplated in $s$ 23(1)(d) by implication, association or subjective interpretation of the agreement".

Assuming that the transacting union or unions have the required majority and that non-parties are appropriately identified and bound by the collective agreement, the rest of this part of the article will explore the meaning of "collective agreement" and "workplace", followed by an illustration of their practical implication.

\section{Workplace}

The meaning of the workplace was central in Chamber of Mines and the litigation leading up to the Constitutional Court judgment. At issue was whether workers at five gold mines, the majority of them represented by the Association of Mineworkers \& Construction Union (AMCU), could exercise the right to strike while an agreement prohibiting strikes, to which their union was not party, was in force with the mining companies who owned the mines. Despite AMCU's majority status at some of the individual mines, it was not the majority union at any of the mining companies. Section 213, unless the context indicates otherwise, defines "workplace" as the place or places where the employees of an employer work. It further provides that "[i]f an employer carries on or conducts two or more operations that are independent of one another by reason of their size, function or organisation, the place or places where employees work in connection with each independent operation constitutes the workplace for that operation." Clearly, if AMCU could show that each mine where it had a majority was an "independent operation" by reason of its size, function or organisation, then it could escape the application of the collective agreement and the implication that it was prohibited from striking on the issues covered by the collective agreement.

The courts a quo, for reasons that can broadly be described as "the organisational methodology and practicalities of each mining company", ${ }^{24}$ all concluded that the five mines were not independent operations and separate workplaces. Hence AMCU and its members were bound by the collective agreement and could not strike on issues covered by it. In endorsing this conclusion, the Constitutional Court observed that "workplace" had been given a special meaning by the legislature, divorced from geography and individuals: ${ }^{25}$ The workplace is not the place where an individual employee works; it is where the employees of the employers work as a collective. ${ }^{26}$ Further, a workplace can constitute several locations as long it forms a functional unit; similarly, each such location can constitute a separate workplace if it is functionally independent of other places where employees of the same employer work. ${ }^{27}$ The Constitutional Court found that neither the

23 Sasol Mining (Pty) Ltd v Association of Mineworkers \& Construction Union (2017) 38 ILJ 969 (LC) par 48. Also see Concor Projects (Pty) Ltd t/a Concor Opencast Mining $v$ Commission for Conciliation, Mediation \& Arbitration (2014) 35 ILJ 1959 (LAC) par 26-27.

24 Chamber of Mines par 31.

25 Par 25-27.

26 Par 25.

$27 \quad$ Par 27. 
context of section $23(1)(d)$, nor constitutional considerations, warranted a deviation from the special meaning assigned to workplace; in fact, both reinforced the application of its special meaning. ${ }^{28}$ This means that a single mine, amongst many owned by a mining company, can constitute a separate workplace, but on the facts of this matter, all the courts agreed that each mining house operated as a single integrated workplace. Since its argument based on the meaning of "workplace" was not successful, AMCU raised, also unsuccessfully, the further argument, dealt with above, ${ }^{29}$ that section $23(1)(d)$, and more particularly the principle of majoritarianism embedded in it, is unconstitutional.

\section{Collective agreement}

In terms of section 213, a collective agreement, unless the context dictates otherwise, means a written agreement concerning the terms and conditions of employment or any other matter of mutual interest concluded by one or more unions, on the one hand, and by one or more employers' organisations, or one or more employers and one or more employers' organisations, on the other hand.

It is useful to reflect on the meaning of the phrase "matter of mutual interest", and more specifically on what it does not mean: The LRA is said to be premised on a division between rights disputes (in respect of which strike action is impermissible and which are to be resolved by way of arbitration or adjudication) and interest disputes (which are to be resolved by way of power-play). In other words, rights disputes are typically resolved by settlement agreements and interest disputes by collective agreements and strikes. However, the term "matter of mutual interest" should not be conflated with these colloquial terms which are used as shorthand explanations for the basic structure of the LRA. The following explanation provided by Van Niekerk $\mathrm{J}$ in Vanachem Vanadium Products (Pty) Ltd $v$ National Union of Metalworkers of $S A^{30}$ clarifies the distinction:

"[A]Il interest disputes (broadly, disputes about the creation of new rights) and rights disputes (broadly, disputes about the interpretation and application of existing rights) are subsets in the broader category of disputes about matters of mutual interest. In other words, all interest disputes constitute disputes about matters of mutual interest, but not all disputes about matters of mutual interest are interest disputes."

Nonetheless, even if an agreement meets the definition of a collective agreement, it is not open season, and the mere fact that it is the result of negotiations between a union or unions and employer/s does not imply that is it fair or that it will survive constitutional scrutiny. ${ }^{31}$ For this reason, discriminatory terms cannot be tolerated simply because they are contained in a collective agreement. ${ }^{32}$ Similarly, POPCRU held that since a collective

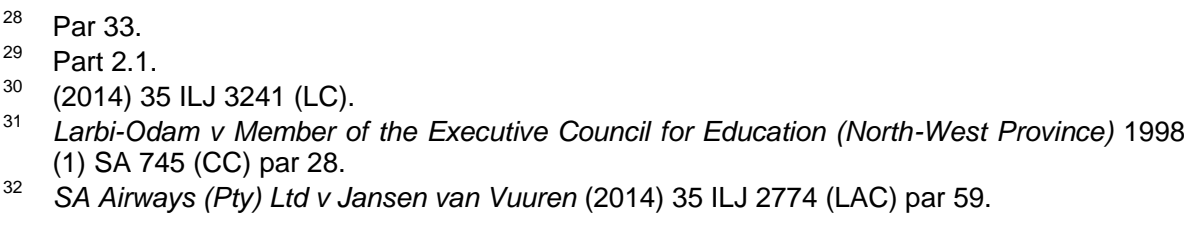


agreement is not a law of general application, it cannot limit a fundamental right $^{33}$ unless the limitation is authorised by legislation. ${ }^{34}$ The remarks of the court related specifically to a possible limitation of the right to engage in collective bargaining through section 18 , but in the end, the court was able to interpret the section in a manner that avoided such limitation. ${ }^{35}$ However, by parity of reason, the same sentiments should be true in respect of any other fundamental right: Collective agreements cannot limit fundamental rights unless there is a legislative provision authorising such limitation. One such provision authorising a limitation of fundamental rights is section $23(1)(d)$; hence the (unsuccessful) attack on it in Chamber of Mines as unconstitutional inasmuch as the limitation related to the right to strike.

\section{Illustration}

The interface between retrenchment and majoritarianism will be explored more fully in Part 3, but a very useful demonstration of the significance of both a "workplace" and a "collective agreement" as building blocks of majoritarianism is provided by the Labour Court's judgment in National Union of Mineworkers $v$ Anglo Gold Ashanti Ltd, ${ }^{36}$ handed down in the context of a retrenchment. The National Union of Mineworkers (NUM) and its members sought to interdict their employer, Anglo Gold, from proceeding with the dismissal of the applicant employees who participated in an unprotected strike. The background was as follows.

As a result of a Constitutional Court ruling ${ }^{37}$ and an amendment of the $\mathrm{LRA}^{38}$ there is now no doubt that employees transfer automatically from the old employer to the new employer when the business is transferred as a going concern. However, it is not always remembered that this consequence can be disrupted by an agreed variation in terms of section 197(6). Anglo Gold commenced with consultations facilitated by the Commission for Conciliation, Mediation and Arbitration (CCMA) in terms of section 189A in respect of all its underground and surface units, one of which a hospital. Anglo Gold secured a buyer for the hospital and concluded an agreement that the hospital would be transferred as a going concern. However, the transfer was subject to a section 197(6) agreement as the buyer did not want to take transfer of all the hospital employees. Nevertheless, at least some of the jobs at the hospital would be saved as a result of this arrangement.

The retrenchment consultation was conducted with four unions (NUM, Solidarity, AMCU and the Aviation Union of Southern Africa (AUSA)), but unlike the other unions, NUM (representing the majority of employees only at the hospital) did not sign the section 197(6) agreement. The applicant employees then threatened to boycott the implementation of the

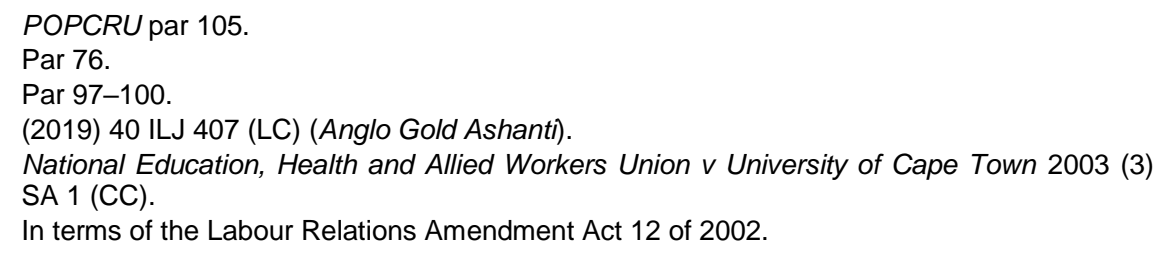


section 197(6) agreement and embarked on an unprotected strike, and were therefore dismissed.

Two broad arguments can be distilled from the judgment. The employer regarded the South African region as one workplace with 7,620 employees. Given that NUM is a minority union, representing only 32.5 per cent of the total number of employees in the South African region (i.e. the workplace), the employer argued that, since the section 197(6) agreement was a collective agreement with the majority unions in the workplace, it was capable of extension and thus applied to NUM and its members. ${ }^{39}$ Countering this, the applicants first argued that the hospital was a separate workplace, and since NUM was the majority union in that workplace (the hospital), an extension could not apply to the hospital. ${ }^{40}$ The judgment is brief and does not provide enough insight into the operations of Anglo Gold, but provides no evidence to contradict the employer's position regarding the confines of its workplace.

The second argument proposed that the section 197(6) agreement was not a collective agreement since it did not deal with a matter of mutual interest. The court held that it clearly did, as it was concluded in the context of a retrenchment process and was informed by the mutual interest of the parties to save jobs at the hospital. ${ }^{41}$ The court further indicated that the extension of the section 197(6) agreement "would absolutely minimise retrenchments and contribute to economic sustainability of both the new and old employers". ${ }^{42}$ Echoing the sentiments expressed by the Labour Appeal Court (LAC) in National Union of Metalworkers of SA on behalf of Members $v$ SA Airways SOC Ltd $(S A A)^{43}$ and discussed further below, the court held that chaos would ensue if a minority union who participated in the retrenchment consultation was allowed to hijack the outcome of a fair process right at the end, as this would undermine the finalisation of the retrenchment process. In other words, majoritarianism expressed in this way is simply code for orderly collective bargaining. Needless to say, the application to interdict the dismissal of the applicant employees was dismissed.

\section{The legality of the extension}

Even if the stars align and a collective agreement is extended, our constitutional dispensation will not allow the capricious use of section 23(1)(d). In Chamber of Mines, AMCU also challenged the constitutionality of section $23(1)(d)$ on the basis that it offends the principle of legality as it allows private actors to exercise public power to legislate over private actors. Cameron $\mathrm{J}$ agreed that "[t]he conclusion of a collective agreement triggering a statutorily licensed extension under $\mathrm{s} 23(1)(d)$ is in its effects and substance an exercise of legislatively conferred public power". ${ }^{44}$

\footnotetext{
Anglo Gold Ashanti par 11-14.

Par 14.

Par 15.

Par 19.

(2017) 38 ILJ 1994 (LAC).

Chamber of Mines par 80.
} 
This, however, is not inimical to our constitutional model as it allows private actors to exercise public power provided that it is exercised rationally. ${ }^{45}$ Section 23(1) (d), by itself, is therefore not irrational, as was argued by AMCU, because it serves a legitimate legislative purpose, namely orderly collective bargaining. ${ }^{46}$ Nonetheless, while the provision itself is not irrational, the power granted by it may not be exercised irrationally. ${ }^{47} \mathrm{An}$ extension under section 23(1)(d) is therefore reviewable under the principle of legality. ${ }^{48}$ In casu, AMCU's argument, which was rejected, focused on the irrationality of section $23(1)(d)$ and not on the irrationality of the extension. As for the latter, there was no evidence or argument placed before the court to support such a claim, ${ }^{49}$ but the principle stands: Parties extending collective agreements may not do so irrationally. The Constitutional Court offered the following example where an extension might be irrational:

"A particular agreement may be vulnerable to attack for irrational and undue effects on minority unions and non-members. An instance might be where parties to a $s 23(1)(d)$ agreement conclude it in flagrant breach of an express agreement with minority unions protecting them from the exercise of the power."

It also does not appear as if an extension will be irrational merely because the minority union was not consulted before the extension. In this regard it has been held that there is "no general duty on decision-makers exercising public power to consult interested parties in order for a decision to be rational under the rule of law" as the entire scheme of the LRA is served by the extension: "It facilitates orderly collective bargaining; it avoids the multiplicity of consulting parties and it fosters peace and order in the workplace. ${ }^{, 51}$

At the very least, a successful attack on the legality of an extension will require evidence that the decision to extend the agreement was mala fide, capricious or arbitrary.

\section{MAJORITARIANISM AND RETRENCHMENT}

\section{Introduction}

A "collective agreement" and a "workplace" are two important building blocks of majoritarianism and, as demonstrated by the judgment in Anglo Gold

45 Par 68-69.

46 Par 67.

47 Par 73 and 83.

48 Par 73.

49 This argument briefly surfaced again in $S A A$ but as no acceptable evidence was presented, the LAC, like the court a quo, declined to review either the collective agreement or its extension under the principle of legality.

50 Par 86.

51 Association of Mineworkers \& Construction Union v Royal Bafokeng Platinum Ltd (2018) 39 ILJ 2205 (LAC) (Royal Bafokeng).

52 Association of Mineworkers \& Construction Union v Minister of Labour (2018) 39 ILJ 1549 (LC); Glencore Operations SA (Pty) Ltd v National Union of Metalworkers of SA (2018) 39 ILJ 2305 (LC). 
Ashanti, are equally relevant in retrenchment situations. Part 3 further explores the manifestation of majoritarianism in retrenchment situations and whether some aspects of retrenchment are immune to the application of majoritarianism.

\section{General}

Initially, all retrenchments were regulated only by section 189 , but since August 2002, section 189A also applies to large-scale retrenchments: It provides an opportunity for third-party facilitation, the choice of disputing substantial fairness through either adjudication or strike action, and an expedited process for procedural unfairness. Some of these privileges can be requested only by certain parties: For instance, only the employer or the consulting parties representing the majority of the employees who the employer contemplates dismissing may ask for facilitation. ${ }^{53}$ However, section 189(1), which identifies the parties that the employer is obliged to consult when it contemplates any retrenchment (small- or large-scale), offers another opportunity for the expression of majoritarianism. It provides that the employer must consult the following parties:

"(a) any person whom the employer is required to consult in terms of a collective agreement;

(b) if there is no collective agreement that requires consultation-

(i) a workplace forum, if the employees likely to be affected by the proposed dismissals are employed in a workplace in respect of which there is a workplace forum; and

(ii) any registered trade union whose members are likely to be affected by the proposed dismissals;

(c) if there is no workplace forum in the workplace in which the employees likely to be affected by the proposed dismissals are employed, any registered trade union whose members are likely to be affected by the proposed dismissals; or

(d) if there is no such trade union, the employees likely to be affected by the proposed dismissals or their representatives nominated for that purpose."

For the purpose of the discussion that follows, it is useful to reflect on the nature of consultations in the case of retrenchment: While the employer is obliged to consult with the consulting parties with an open mind, it has no duty to reach consensus and it may proceed with the retrenchment once it is satisfied that it has consulted in a meaningful way. ${ }^{54}$ The strongest statutory indication of this is section 189(7), which provides that, in the absence of agreed criteria, the employer may select employees for retrenchment using fair and objective criteria and, despite being backed up by the right to strike, this remains the position in large-scale retrenchments. Thus, while consultations may often, especially in the case of large-scale retrenchments, morph into collective bargaining and culminate in a collective (retrenchment) agreement, there is no statutory obligation to conclude a retrenchment

\footnotetext{
$S 189 \mathrm{~A}(3)(b)$.

Le Roux Retrenchment Law in South Africa (2016) 92-93.
} 
agreement; it remains the choice of the parties whether to conclude such an agreement. $^{55}$

Nonetheless, where the consulting parties, or some of them, conclude a collective agreement in these circumstances, it has been said that the voluntarist system and policy choices (such as majoritarianism) on which the LRA is premised should take their course ${ }^{56}$ However, over the last few years, as large-scale retrenchments are escalating in South Africa, it has been questioned how far this can go in retrenchment situations.

In the discussion that follows, for ease of reference, a distinction is made between a collective agreement contemplated by section 189(1)(a) (consultation agreement), determining who must be consulted about the proposed retrenchment, and a collective agreement (retrenchment agreement) that is concluded after consultation and in which the parties record any agreement on the issues that the parties are required to consult on in terms of section 189(2) and any further issues.

\section{No consultation agreement, but a retrenchment agreement}

If there is no consultation agreement, but a retrenchment agreement is concluded after the consultations required by section 189, it is possible to extend it in terms of section 23(1)(d) and thus for majoritarianism to manifest in this manner. Nonetheless, the long-standing precedent ${ }^{57}$ in this regard was questioned in the litigation that culminated in the LAC's judgment in $S A A^{58}$

South African Airways (SAA), the national carrier, and a subsidiary commenced with retrenchment consultations and a single facilitation process was agreed upon. The majority of employees at SAA belonged to one of the three unions recognised by SAA: the National Transport Movement (NTM), the SA Cabin Crew Association (SACCA) and the United Association of SA (UASA). Less than 2 per cent of SAA's employees were members of the National Union of Metalworkers of South Africa (NUMSA), which was unrecognised. Nonetheless, all these unions, as well as management representative bodies, participated in the consultation process facilitated by the CCMA. Very belatedly, and after three and a half months' facilitation and 31 consultation meetings, NUMSA brought an application in the CCMA for the disclosure of information relating to the commercial rationale for and alternatives to dismissals. While this application was pending, SAA concluded a retrenchment agreement with NTM, UASA, SACCA and SAA management employees, representing roughly 80 per cent of employees in the SAA workplace. The agreement was extended to non-party employees in terms of section 23(1)(d). At this point, NUMSA launched an application in

55 Aviation Union of Southern Africa v SA Airways SOC Ltd (2015) 36 ILJ 3030 (LC) (Aviation) par 36-38.

56 lbid.

57 Tsetsana v Blyvooruitzicht Gold Mining Co Ltd [1999] 4 BLLR 404 (LC); Sigwali v Libanon (A Division of Kloof Gold Mine Ltd) (2000) 21 ILJ 641 (LC).

58 The judgment of the court a quo is reported as Aviation. 
terms of section $189 \mathrm{~A}(13)$ with the aim of interdicting SAA from proceeding with a large-scale retrenchment until it had complied with a fair procedure. The LAC saw the essential question for determination as follows:

"[W]hether a retrenchment agreement concluded with unions representing the majority of employees in the workplace, and extended in terms of $s$ 23(1) (d), in effect settled any dispute that non-union member employees and minority union members [who ${ }^{59}$ participated in the consultation] had about the retrenchment process.

Both the LAC and the court a quo conceded that it might appear objectionable that section $23(1)(d)$ can effectively deprive individuals who were not party to the retrenchment agreement of the right to challenge the fairness of a dismissal (retrenchment in this case), but regarded it as inevitable that an extension of a collective agreement will have this effect on non-parties, as is often demonstrated by the implied limitation on the right of non-parties to strike on issues covered by the collective agreement once the latter is extended. ${ }^{60}$

A number of interesting arguments were raised by NUMSA, all of which were rejected. To again illustrate the significance of a collective agreement as a building block of majoritarianism, it is illuminating to focus on NUMSA's contention that a retrenchment agreement such as the one concluded between SAA and the majority unions was in effect not a collective agreement and therefore could not be validly extended to non-party employees. ${ }^{61}$ Instead, NUMSA argued that it constituted a settlement agreement that was binding on only the parties and their members and was not a collective agreement capable of extension to non-parties. ${ }^{62}$ In supporting this proposition, NUMSA argued that the words "(or) any other matter of mutual interest" in the definition of a collective agreement served to qualify and circumscribe the preceding words "terms and conditions of employment" and restricted collective agreements to matters of interest (i.e. the creation of new rights) and not rights issues (existing rights). Since the issue at stake concerned a dismissal dispute (i.e. a rights dispute) the retrenchment agreement, so NUMSA argued, was not a collective agreement. $^{63}$

The LAC, mentioning that interest disputes are frequently incorrectly conflated with matters of mutual interest, ${ }^{64}$ concluded that "the issues covered in s 189(2) of the LRA are manifestly mutual interest issues" and that a "retrenchment agreement between an employer and a trade union settling a retrenchment dispute is therefore a collective agreement". ${ }^{65}$ As a result, once a retrenchment agreement meets the requirements of the definition of a collective agreement in section 213 it can be extended, as there is nothing in the scheme of sections 189 and 189A that militates against this conclusion:

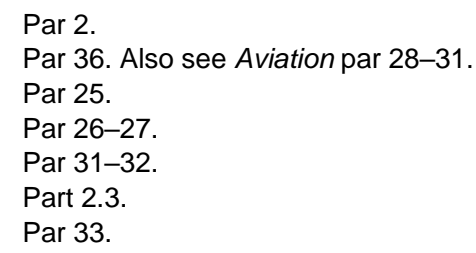




\begin{abstract}
"The application of $s 23(1)(d)$ of the LRA to the process set out in $s 189$ of the LRA is necessary and justifiable to ensure an orderly and peaceful consultation process aimed at minimising dismissals and contributing to economic viability. To allow a situation where a minority party would, right at the end of the consultation process, not be bound by a product of a legitimate and fair process, particularly where it was part of that process, would lead to chaotic situations. It would be difficult, if not impossible, for a consultation process under $\mathrm{s} 189$ of the LRA to be concluded.
\end{abstract}

However, significantly, on the facts of SAA, the employer apparently met its consultation obligations in terms of section $189(1)$ by consulting with the unions whose members were likely to be affected by the proposed dismissals and the representatives of non-unionised employees. The question of whether the principles of majoritarianism apply in the same way to consultation agreements is discussed below.

\title{
34 Consultations and consultation agreements
}

The discussion in the previous paragraph assumed that the employer consulted with all the consulting parties with which it was required to consult. But what is the status of the various consulting parties mentioned in section 189(1) and can majoritarianism be used to deprive them of a seat at the consultation table?

The courts have often held that section 189(1) represents a hierarchy of consulting parties. ${ }^{67}$ However, care should be taken with the meaning of this proposition: If it implies that the mere existence of a consulting party mentioned in section 189(1) creates a hierarchy that displaces all the consulting parties lower down in section 189(1), and more particularly that the mere existence of a consultation agreement in terms of section 189(1)(a) will have this effect, then it is suggested that it is wrong (scenario 1). If it implies that consulting parties mentioned in section 189(1)(b) to (d) are displaced once a consultation agreement is extended in terms of section $23(1)(d)$, there might be some merit in the proposition, although some reservations are expressed below (scenario 2).

It is not easy to distil the jurisprudence on this issue because it often mentions consultation with a "recognised" union as if that is the same as consultation in terms of an extended consultation agreement. ${ }^{68}$ The mere fact that a union is recognised for collective bargaining purposes, however, cannot be taken to imply that it is the consultation representative for all employees affected by the retrenchment. Unless the collective agreement clearly envisages consultation for retrenchment purposes and both identifies and expressly binds the non-party employees, an extension cannot be

66 Par 39.

67 Sikhosana v Sasol Synthetic Fuels (Sikhosana) (2000) 21 ILJ 649 (LC) 656D-G; SA Municipal Workers Union v SA Local Government Association (2010) 31 ILJ 2189 (LC); Maluleke v Johnson Tiles (Pty) Ltd (2008) 29 ILJ 2606 (LC) (Maluleke); Mahlinza v Zulu Nyala Game Ranch (Pty) Ltd [2004] JOL 12459 (LC); Ketse v Telkom SA SOC Ltd (2015) 36 ILJ 1592 (LC) (Ketse).

68 Sikhosana; Aunde SA (Pty) Ltd v National Union of Metalworkers of SA (2011) 32 ILJ 2617 (LAC) (Aunde). Also see Aviation and Ketse. 
implied by the fact that a particular union is a "recognised" union. For instance, in Aunde the employer entered into a recognition agreement with UASA in terms of which it was recognised as "the sole bargaining representative of the employees in the bargaining unit for all other workrelated plant level issues, including any need to consult as required by the LR". ${ }^{69}$ In addition, the parties agreed to negotiate a retrenchment procedure. The LAC held that the duty to consult in terms of the recognition agreement with UASA envisaged consultation in terms of Chapter III of the LRA, otherwise the term providing for the negotiation of the retrenchment procedure would serve no purpose. ${ }^{70}$ Consulting only with UASA about the proposed retrenchments therefore did not relieve the employer of its consultation obligations.

The scenarios mentioned above are explored in more detail below.

\section{Scenario 1: There is a consultation agreement, but section $23(1)(d)$ is not invoked}

Where the consultation agreement is not extended, ${ }^{71}$ it is suggested that there is no "winner takes it all" consulting party. Inasmuch as a "hierarchy" can be said to exist, it should rather be understood as a means of avoiding dual or parallel consultation. ${ }^{72}$ To suggest otherwise would not only make a mockery of the model of majoritarianism envisaged by the LRA, but would also give unprecedented power to a minority union in the case of retrenchment.

For the mere existence of a consultation agreement (i.e. a collective agreement not extended in terms of section $23(1)(d)$ ) to remove the need to consult with the consulting parties mentioned lower down in section 189(1), two extraordinary hurdles must be negotiated: First, such a collective agreement must have a special meaning in the context of sections 189 and $189 \mathrm{~A}$ and second, section 23, in particular section 23(1)(d), which determines who is bound by a collective agreement, must somehow not apply in the case of a retrenchment agreement.

Section 23 determines who is bound by a collective agreement: Usually a collective agreement will bind only the unions, employers and employer organisations party to the collective agreement as well as their members. ${ }^{73}$ It is only in exceptional cases, i.e. when the requirements of section 23(1)(d) are met, that non-parties are bound. A claim that any consultation agreement, even one not extended in terms of section $23(1)(d)$, will dislodge the right to be consulted of those consulting parties mentioned lower down in section 189(1) will thus be a peculiar disregard of section $23(1)(d)$ and the safeguards offered by it. Not only is there no suggestion in sections 189 or $189 \mathrm{~A}$ that this particular extraordinary meaning can be assigned to a

\footnotetext{
Aunde par 16 .

Aunde par 38.

This might be because it is not with a majority union or the other "soft" requirements of s 23(1)(d) are not met.

72 Baloyi v M \& P Manufacturing (2001) 22 ILJ 391 (LAC) (Baloyi) par 23.

$73 \mathrm{~S} 23(1)(a)-(c)$.
} 
collective (consultation) agreement mentioned in section $189(1)(a),{ }^{74}$ but as will be demonstrated below, section 189(1) is reasonably capable of another interpretation that does not violate the rights of employees if it is viewed through another prism, namely, avoidance of dual consultation.

If an employee is covered by a consultation agreement, consultation regarding that employee takes place in terms of the consultation agreement and the options lower down section 189(1) fall away and no individual consultation with that employee is required. ${ }^{75}$ This means that an employer may fairly discharge its consultation duties without consulting individually with an affected employee. ${ }^{76}$ However, where the employee is not covered by the consultation agreement, but is a member of a union not party to the consultation agreement, the "hierarchy" requires that that union be consulted and not the employee. ${ }^{73}$ It is only when the employee is not a member of a union that direct consultation with the employee is required. ${ }^{78}$

Put differently, section 189(1) does not imply that the employer will discharge its consultation obligations if it consults with the union party to the consultation agreement if it also contemplates the retrenchment of members of a non-party union. ${ }^{79}$ It simply means that in respect of employees covered by the consultation agreement, the employer is obliged to consult in terms of the consultation agreement. In the absence of a consultation agreement and for other affected employees not covered by the consultation agreement, the employer must look for appropriate consulting parties lower down section 189(1). If these employees happen to belong to a union, that union will be the appropriate consulting party. The employer is required to consult directly with the employees only if they do not belong to a union at all (although section 189(1)(d) allows these employees to nominate a representative). This appears to have been the scenario in SAA: There was no consultation agreement, but the employer consulted with all the unions to which the employees belonged, as well as the representatives of those employees who did not belong to a union.

Furthermore, a suggestion that any consultation agreement invokes a "hierarchy" that displaces the consultation parties lower down section 189(1) would run foul of POPCRU: Such an interpretation will result in a limitation of the right to procedural fairness embedded in the constitutional right to fair labour practices of employees belonging to non-party unions and would be of no force and effect unless such a limitation was authorised by legislation. The only legislative mechanism by which such a limitation can possibly be invoked is section 23(1)(d), but where its requirements are not met, the consultation agreement can apply only inter partes. There is simply no indication in sections $189,189 \mathrm{~A}$ and 23 that a consultation agreement as referred to in section $189(1)(a)$ by itself is capable of a special meaning that

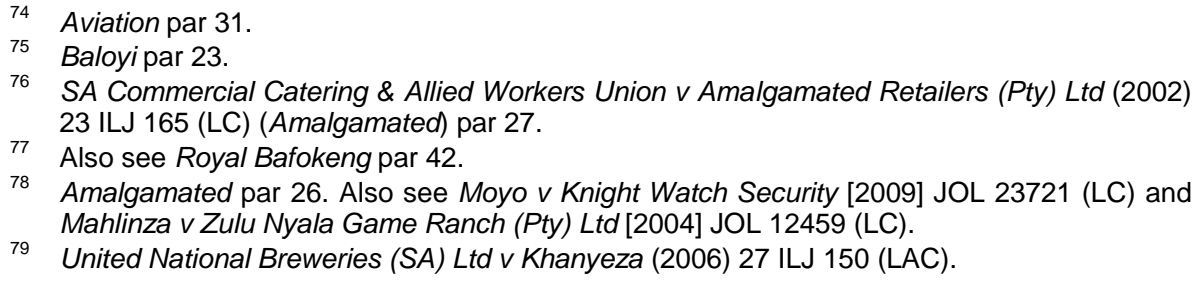


in effect negates the legislative authority (section $23(1)(d)$ ) for the limitation of fundamental rights. ${ }^{80}$

It is suggested that by adopting the scheme in section 189(1), which removes the need for dual consultation, the legislature was not only alive to the difficulties of consulting with multiple parties and in this way attempted to lessen the burden on the employer, but it was also alive to the ILO's position that procedural fairness in the case of retrenchment can also be met by consulting with the workers' representative instead of consulting directly with individual employees. ${ }^{81}$ Herein, it is suggested, perhaps lie the seeds for assigning special meaning to a consultation agreement, but different from what has been proposed thus far. This will be reverted to below.

\section{Scenario 2: There is a consultation agreement and section $23(1)(d)$ is invoked}

In respect of this scenario, the jurisprudence is established that once the consultation agreement is extended, a hierarchy is invoked and the employer "has no obligation in law to consult with any other union or any individual employee over the retrenchment". ${ }^{82}$ And if this leads to the conclusion of a retrenchment agreement, "all employees including those who are not members of the representative trade union that consulted with the employer are bound by the terms of such collective agreement irrespective of whether they were party to the consultation process or not". ${ }^{83}$ In other words, if non-party employees are retrenched in accordance with the retrenchment agreement, they are effectively deprived of the right to dispute the procedural fairness of their retrenchment.

This wisdom was challenged in Royal Bafokeng. ${ }^{85}$ The appellant employees received notices that they would be retrenched. AMCU, their union, was not consulted on their retrenchment and neither AMCU nor the employees were issued with section 189(3) notices. The employer and NUM (the majority union) and UASA, another union at the mine, signed a consultation agreement in terms of which the employer was required to consult exclusively with NUM and UASA in the case of retrenchment. NUM and UASA were duly consulted, and the parties then concluded a retrenchment agreement that was extended to bind employees who were not members of NUM or UASA. These included the members of AMCU. By the time the matter reached the LAC, the Constitutional Court had already spoken in Chamber of Mines, and no issue was taken with majoritarianism and its constitutionality in general. Instead, the gripe was limited to the

80 There is one exception to the claim that $s$ 189(1) aims to avoid dual consultation, but it ought only to arise in the circumstances of scenario 2: Where an employer initiates consultation with non-union members with whom it is not required to consult (because they are covered by an extended consultation agreement), it is obliged to carry that election through and must attempt to reach consensus with those employees in the same manner as with the statutory consulting party. Amalgamated par 26.

Article 13 of the ILO Convention on Termination of Employment 158 of 1982.

Aunde par 32.

Ibid. Also see Maluleke.

4 Aunde par 32

85 (2018) 39 ILJ 2205 (LAC). 
application of majoritarianism in respect of the right to procedural fairness in the case of retrenchment, and more particularly the implication of section 189(1)(a) combined with section 23(1)(d) that once an employer and a majority union concluded a consultation agreement, constituencies not party to the collective agreement were excluded from retrenchment consultations and hence denied a fair process. In short, the judgment concluded that this expression of majoritarianism too is not unconstitutional. Three aspects of the judgment merit mention.

First, the court observed that collective bargaining and the conclusion of collective agreements are fundamental aspects of the voluntarist structure of the LRA. Collective agreements are therefore deliberately powerful instruments and, once validly concluded, can disrupt the provisions of the LRA. $^{86}$

Second, the court drew a distinction between misconduct and incapacity dismissals and retrenchment. The court alluded to the ILO's guidance that procedural fairness in the case of dismissals is met by giving the employee an opportunity to defend herself, and in the case of retrenchments, by the employer consulting with workers' representatives. Allowing the most representative union to have an exclusive seat at the consultation table in the case of retrenchment serves the interest of the employees optimally, ${ }^{87}$ avoids the impracticability of the employer having to consult with numerous constituencies, and avoids the risk of a minority union being able "to frustrate mass retrenchment ... [which] would cause bedlam and chaos at the workplace" ${ }^{88}$ All of this, so the court concluded, serves orderly collective bargaining. ${ }^{89}$

Finally, this arrangement does not imply that those constituencies not consulted are not represented. The majority union, having won the right to be the representative union, has a duty to represent fairly and without discrimination both its members and non-members. The employer has a similar duty to act fairly towards minority unions and non-unionised employees. If these duties are not observed, a retrenched employee has the right to challenge the fairness of the individual dismissal. ${ }^{90}$

Royal Bafokeng thus confirms that once a consultation agreement is extended, the employer need not consult with a union that is not party to the consultation agreement, even if its members are likely to be affected by the proposed retrenchment, nor with non-unionised employees who are likely to be affected by the proposed retrenchment. ${ }^{91}$

Nonetheless, the outcome does leave one with a sense of unease, because an employee facing an existential crisis is left without representation of his or her choice at the consultation table. It is therefore no surprise that this decision was appealed against in the Constitutional Court. The unease is best expressed by listing a few questions and observations.

\footnotetext{
Par 24-25.

Par 39.

Par 42.

Par 39.

Par 50-52.

Le Roux Retrenchment Law 88.
} 


\section{Questions and observations}

Can it really be said that a union that has won the right to represent all the employees through statistical dominance will be able to fairly represent a niche group of employees (or employees belonging to a rival union) with interests different to, or even in conflict with, the interest of employees belonging to the majority union? In terms of the Constitution, ${ }^{92}$ everyone has the right to fair labour practices, which implies a right to a procedurally fair dismissal regardless of the form the dismissal takes. Procedural fairness arguably includes the right to representation, although it is widely accepted that in workplace disputes, this does not imply a right to legal representation, but only representation by a fellow employee or union representative. Royal Bafokeng suggests that in the case of retrenchment this entitlement is met even when an affected employee is represented, not by a union the employee has chosen to join, but by a union the employee has chosen not to join. ${ }^{93}$ Even if it could be argued that this is sufficient to meet the right to procedural fairness, it still comes worryingly close to what both Bader Bop and Chamber of Mines cautioned majoritarianism should not do, namely to undermine, amongst others, the freedom of association of individual employees.

Clearly having collective representation in the case of retrenchment as opposed to allowing each employee to be heard as in the case of misconduct and incapacity dismissals is rational, ${ }^{94}$ but while majoritarianism might be justified in the circumstances of Royal Bafokeng for other reasons, the claim that a multiplicity of consulting parties will be unworkable or cause bedlam is not valid. In $S A A$, the employer consulted with multiple parties and while the process was cumbersome, it was not insurmountable. More particularly, involving the minority unions during consultation did not allow them to keep the majority hostage. Not only does section 189 not require the employer to reach consensus with consulting parties, but it allows the employer to proceed with the retrenchment using fair and objective criteria once the employer has consulted in a meaningful way. In any event, as was illustrated in SAA (and also in Anglo Gold Ashanti), through the extension of a retrenchment agreement, recalcitrant minority unions were prevented from derailing the finalisation of retrenchment, but, unlike the situation in Royal Bafokeng, they at least had a seat at the consultation table. Furthermore, there are other legislative examples where an employer is required to consult across various interest groups without any reports of bedlam.$^{95}$ Also, the legislature recognised the difficulty of consulting with individual employees in the case of retrenchments and for that reason provided the regime in section 189(1) which, as proposed above, avoids dual consultation and minimises the need to consult with each employee.

S 23(1) of the Constitution.

3 Although in the context of misconduct, Independent Municipal and Allied Trade Union (IMATU) v South African Local Government Bargaining Council (JR2462/18) [2019] ZALCJHB 240 (12 September 2019).

94 Royal Bafokeng par 54.

95 See s 16 of the Employment Equity Act 55 of 1998. 
Earlier it was argued that there is no indication that a consultation agreement in section 189(1)(a) has a special meaning to the effect that it removes the employer's obligation to consult the parties mentioned lower down in section 189(1) without it being extended in terms of section 23(1)(d). However, would representation by a disconnected union by means of an extension of the consultation agreement not militate against the special regime established by the legislature in section 189(1)? In other words, does the context of section 189(1) not suggest that a consultation agreement in terms of section 189(1)(a) in fact has a special meaning but of a different nature to what has thus far been proposed, namely that section 23(1)(d) cannot apply to it?

In Royal Bafokeng, the applicants' arguments ${ }^{96}$ based on unfair union discrimination were rejected, correctly, it is suggested. It probably is inevitable that majoritarianism will cause some deprivation to members of minority unions or non-unionised employees. Deprivation is therefore not the issue; rather, the concern should be with what they can be deprived of. If one fundamental right, i.e. the right to strike, can be limited through an extension, on what basis can it be said that another fundamental right cannot be limited in a similar way? Chamber of Mines confirmed that the right to strike of the members of minority unions can be limited through an extension of a collective agreement because majoritarianism, thus expressed, serves orderly collective bargaining, but does the same hold true for a fundamental right that is not essential to collective bargaining? While the right to strike belongs to an individual employee, it can only be exercised collectively and is necessary for an effective exercise of the right to collective bargaining. If majoritarianism is a means of ensuring orderly collective bargaining, does it not follow axiomatically that it can limit only fundamental rights promoting collective bargaining, but not individual rights (such as the right to procedural fairness) that serve no particular purpose in promoting collective bargaining, as this would allow majoritarianism to become an instrument of oppression?

\section{CONCLUSION}

This article has demonstrated that, first, while majoritarianism might be a premise of the LRA, it is not a foregone conclusion: It requires a collective agreement in a workplace concluded with a majority union extended in the manner provided for in section $23(1)(d)$. Second, majoritarianism has tentacles that can reach deep into, and then twist, some of the fundamentals of the LRA. The question is whether there are aspects of the LRA, such as retrenchment, that are or ought to be, immune from its reach.

In Chamber of Mines the Constitutional Court endorsed majoritarianism as a constitutionally valid instrument of orderly collective bargaining that can validly limit the right to strike. Whether it can also limit fundamental rights not promoting collective bargaining is awaiting pronouncement by the Constitutional Court in Royal Bafokeng, after the LAC ruled that the right of employees to be represented by their own union during retrenchment

$96 \quad$ Par 32 and 35. 
consultations can be limited by an extension of a consultation agreement. Therefore, as the jurisprudence currently stands, retrenchment is not exempted from majoritarianism.

This article advanced a number of reasons why this ruling might be overturned, but the reality is that majoritarianism is a blunt instrument in service of broad workplace order and is perhaps not capable of accommodating the nuances advanced in this article. The Constitutional Court, one suspects, will therefore take great care, like the court a quo, not to interfere with the thread of majoritarianism in regard to consulting partners in the case of retrenchment, because this "might unravel the entire sweater woven by the legislator". ${ }^{97}$ It is therefore perhaps better, as hinted by the court a quo, ${ }^{98}$ for the legislator to provide the finesse that is currently missing.

Royal Bafokeng par 55

98 Ibid. 